\title{
Reading the Gendered Body in Filipino-Australian Diaspora Philanthropy
}

\section{Shirlita Africa Espinosa, University of Sydney}

This essay interrogates the phenomenon of diaspora philanthropy that only recently has gained the attention of scholarly and financial institutions in relation to Filipino migrants in Australia. With a particular focus on the Sydney Fiesta Cultura's yearly celebration of Filipino 'identity,' I present and clarify the links between transnational giving and a migrant community's sexualised citizenship, and then problematise how this relationship is grounded specifically in the 'mail-order bride' as a gendered subject. 'Mail-order bride' is an Australian colloquialism that emerged in the 1970s for Filipino women who married Anglo-Australians, with the pejorative implication that such women were either prostitutes or prepared to marry for financial gain.

As an ethnographer observing and participating in well-attended festivities that showcased a wealth of material culture practices, and the consumption and production of immigrants in Sydney, I saw how the Sydney Fiesta Cultura celebration avoids any recognition, return, remembrance, let alone direct repudiation, of the community's ambivalently feminised migration. This feminine migration, however, is tacitly subverted by the very performance of a beauty contest amongst second-generation young women-some of whom are children from socially ostracised interracial marriages - which then take new forms in the discourse of diaspora philanthropy. Contextualised within the ever-growing scholarship on international migration, labour movement and the feminisation of migration in the domestic and service sphere, including those who migrate as partners, this paper on Filipino-Australians explores the politics of solidarity extended through charitable gestures hinged upon the marginalised 
figure of the 'mail-order bride,' a spectre who inhabits the liminal spaces that the 'third world' woman migrant is permitted to occupy. Given that the Filipino woman in Australia is markedly hyperfeminised, I find it problematic for 'ethnicity entrepreneurs' (Kasinitz 1992: 163), such as the producers of Sydney Fiesta Cultura, to seize the opportunities that diaspora philanthropy opens to them without reflecting on the community that they have appropriated to serve.

In this article, I discuss the emerging area of diaspora philanthropy and examine how Filipino-Australians’ material practices and everyday culture contribute to that phenomenon. Second, I briefly describe the composition of Filipino migration and the sexualisation of Filipino citizenship in Australia as a result of the racist and sexist fantasies of a 'neo-fascist' multicultural nation making sense of its loss of centrality amidst the influx of non-white migrants (Hage 1998: 26). Lastly, I examine how the embodiment of women in community performances (or performances as embodiment of a gendered community) such as a beauty contest complicates and questions — rather necessarily - the positive, ethical philosophy of philanthropy. Reading the practice of diaspora philanthropy through feminism may be read as contaminating what is 'good' about that particular form of philanthropy; but it is, I argue, a necessary reading.

\section{Migrant Fiesta as a platform of giving}

The amount of money remitted by Filipinos overseas in 2010 alone, according to the World Bank, was US\$18.8 billion. This puts the Philippines after India, China and Mexico as the top four senders of transnational earnings (Torres 2011). While money transfers have been easily quantified and then analysed as part of the broader trends in human migration in recent times, what accounts as diaspora philanthropy has not been summarily calculated. This form of philanthropy can take forms as varied as financial investments, technology transfers, human resource exchanges, equipment, grants, emergency aid, and medical missions. Although not new as a form of transnational migrant material practice, diaspora philanthropy does not attract as much scholarly attention as that given to direct money transfers families receive to keep them afloat, for these remittances are allotted for food, utilities, educational expenses, rent and other basic needs. Diaspora philanthropy - that which does not directly benefit families for private purposes—sometimes called 'homeland philanthropy,' migrant philanthropy,' and 'transnational giving,' is generally articulated as civic responsibility or public action 
(Johnson 2007: 5). Like the practice of remitting monthly living allowances to one's family, a practice conditioned by South-to-North migrations across the world, diaspora philanthropy necessitates a new framework that veers away from Western definitions of giving, and being philanthropic, and even benevolent.

While diaspora philanthropy patterns itself on the altruist philosophy of giving in the West, it is conditioned by very different social relations between givers and receivers and, in turn, results in new economic formations in the old country. For instance, does the diaspora philanthropy of Filipinos in the USA, Australia or Canada to Filipinos in the Philippines resemble the definition of 'generosity,' and reach the standard of what is to be given within the cultural parameters, of the West or that of the old country? The balikbayan box (literally 'homecoming' box) that overseas Filipinos diligently fill with things - from canned goods, to second-hand clothes, toys, complimentary pens, winter jumpers, and all imaginable knickknacks - and then send to relatives who gracefully receive the unsuitable, at times useless, 'gifts,' can be a microcosm of the 'cultural' specificities of philanthropy. Take, for instance, a tiny concrete waiting shed in the town of Calamba, Laguna, where a boldly painted sign reads: 'A gift from the FilipinoAmerican Association of San Diego, California, USA.' The production of desires, in particular of fantasies of overseas migration, which this waiting shed and what it stands for engenders in every person in the town, or perhaps in passersby who resent its construction, is facilitated by diaspora philanthropy. Yet, as Northern countries tighten their migration intake of low-skilled 'third world' citizens who do not exhibit the same 'flexibility' as their high-skilled cosmopolitan counterparts (Ong 1999), the feeding off from transnational desiring that underpins diaspora philanthropy could be interpreted as symbolic violence to those left behind and not as a gesture of goodwill. Do questions such as 'what is to be given' and 'in what physical forms and social contracts should giving take place' undermine the spirit of transnational giving? Or are these questions comfortably glossed over in the name of the liberalism by which benevolence without accountability is ontologically possible?

Peggy Levitt (2002) raises the point that migrants' mobilisation of their human and financial resources is a self-regulatory mechanism in situations where state intervention is not immediate. Like views critical of money remittances as only palliatively dealing with the causes of inequity of wealth amongst nations and the concentration of global 
capitalism in select cities, diaspora philanthropy lets government initiatives become auxiliary to resources pumped by external sources; at times local officials simply become enactors of migrant projects (Geithner et al. 2005). For example, the Ayala Foundation, a private organisation established by the Ayala Corporation, 'the largest conglomerate in the Philippines,' has had a branch in the USA since 2000. As it can operate freely in the Philippines, the US branch constructs itself as a 'bridge of hope across the seas' that oversees donations from Filipino-Americans for poverty-reduction programs without the need to liaise with the Philippine government (Garchitorena 2007: 16). From 2002 to 2006, the Ayala Foundation USA facilitated the transfer of US\$2.8 million of cash and in-kind donations from Filipino-Americans to the Philippines. It is not difficult to see how transnational giving is caught in the cycle of economic and social changes that order market demands and arrange peoples' lives and geographies. Migrants return resources to the countries they left behind as a result of the neoliberalist deregulation of labour markets and the segregation and subsequent valorisation of the skilled over the non-skilled, where labour is either outsourced or arbitraged (Ong 2006: 160-63). Diaspora philanthropy narrows and minimises government intervention in public welfare. Emma Bell's study of neoliberalism and criminal justice notes the 'new welfarism,' whereby individuals are taught to 'responsibilise' and self-regulate; this subsequently gives rise to the 'punitive turn' of states as the old social order is replaced (2011: 20-21). The worldwide income gap has been partially improved by the remittances and diasporic charity resulting from the movement of labouring bodies. A total of US\$440 billion dollars of remittance transfers was reported in 2010 (World Bank 2011: x). The rising share of money transfers in the GDP of developing nations in Asia, Africa and Central America where as much as 35 percent (Tajikistan) of a country's GDP is sourced from remittances prove the enormous potential of migrant philanthropy to relieve states from the responsibility to provide social services (World Bank 2011). It could be said that neoliberal labour has 'responsibilised' migrants to look after non-migrants back home. Such a formulation is often expressed in nationalist terms, as a personal and yet also as a political affair of migrants. If migrants do not give back, who will?

The entrapment of migrants in the machinery of physical exodus and transnational economic returns is better exemplified by philanthropy organised around the 'hometown associations’ commonly established by migrants from Mexico, Central America and the 
Caribbean (Orozco \& Rouse 2007; Orozco \& Welle 2009) but also from the Philippines. These migrant associations, especially those formed by migrants from rural areas, are often focused on the alleviation of poverty and contributing to local infrastructure, while 'hometown associations' from China, India and Taiwan extend philanthropy as capital investment to spur business activities (Johnson 2007: 11). There are many examples of Filipino 'hometown associations' in Sydney, some of which I was acquainted with while doing fieldwork. Bicolanos in Sydney is active in pulling resources together to finance scholarships for impoverished students, build infrastructure, and enable medical and dental missions. A fundraising dinner I attended in 2009 in Blacktown, New South Wales, was a good example of a 'hometown association' in action; the event made visible how the 'local-transnational-local' chain of geographies is formed with the support of (white) Australian politicians.

However, philanthropic landscapes may create unevenness amongst those on the receiving end. There are areas in the 'third world' where human development index scores are higher and are more likely to send their locals to overseas destinations than less fortunate areas. This means that places with higher outgoing migrant density have a greater chance to reap benefits from diaspora philanthropy and remittances and to accumulate economic and social capital over the years. Those with little 'migrant investment,' however, are doomed to remain impoverished, particularly when states have concentrated capital in the development of urban zones and technology parks. The unevenness of this 'development' continues if certain places cannot sustain patterns of earlier migration. Today, the town of Mabini in the province of Batangas, south of Manila, is known for the hundreds of locals who left for Italy to provide domestic service. The 'new money' sent for about four decades has developed the town into a more urbanised space amidst tracts of farmland (Basa et al. 2009: 15-17). The town is called 'Little Italy,' reflecting how returned migrants have built Mediterranean-inspired houses, opened 'Italian' restaurants, financed the paving of the town's roads, and established vineyards as an homage to the culture and people they were exposed to as servants. Mabini has been frequently cited as an example of the successes of labour migration; the small town has become a curiosity for tourists passing by the province. But for how long will this migration pattern last? Do the better-educated children of these labour migrants stay in the Philippines - the ultimate goal is to reunite the 
family_ or do they embark on a new migration pattern? These are questions raised by the long-term effects of diaspora philanthropy.

The practice of migrant philanthropy amongst Filipino-Australians does not attract added scrutiny given the 'commonness' of benevolence in liberal democratic societies. In 2009, when typhoon Ondoy flooded Manila and its surrounding provinces, Sydneybased Filipinos immediately responded. A local businesswoman, Emma de Vera, initiated relief efforts (disaster philanthropy) that saw the delivery of dozens of boxes of goods to the Philippines. ${ }^{1}$ The same principle drives faith-based giving, an example of which is the friendly bowling tournament of Filipinos in the working class suburb of $\mathrm{Mt}$ Druitt, a known ethnic 'enclave’ of Filipinos west of Sydney, to raise money for the urban poor in Manila. The Christian Bowling Sports Fellowship is an annual competition held on Sundays that gathers several religious formations: Love of Jesus, Filipino Christian Fellowship, Western Sydney Christian Church, God is Good, Come to Jesus Church and Punch Bowl Baptist Church. According to its organiser, the tournament's budget for the group’s Christmas mission in the Philippines was AU\$10,300 in 2009. ${ }^{2}$ These two examples, however, depart considerably from the Sydney Fiesta Cultura's appropriation of Miss Philippines-Australia. This competition is characterised by its prestige in the community and its mobilisation of migrant networks, and involves selected second-generation young Filipino-Australian women vying for the special title, Miss Charity Queen Australia. The title goes to the candidate who sells the most tickets. More than a beauty queen, she becomes the embodiment of diaspora philanthropy. Charity Queen inscribes the whole exercise of pageantry into an act of transnational benevolence. Her body is where philanthropy is borne and exercised, the cause of giving and the effect of being given. But why is this discursive production of docile bodies in the name of migrant philanthropy be of concern, given the 'ordinariness' of pageants amongst Filipinos in the Philippines and those in the diaspora?

\footnotetext{
${ }^{1}$ Interview with Emma de Vera in Granville, NSW, on March 28, 2010. De Vera, a former accountant, who now runs a printing shop, volunteered her shop to collect the in-kind donations from Filipinos and Australians alike in Sydney. She narrated to me how good it felt to help those in need in the Philippines especially because she and her family have done very well in Australia.

${ }^{2}$ Interview with Joey Espinosa in Mt Druitt, NSW, on September 27, 2009. I met Espinosa through a serendipitous meeting with a man who heard me as I conducted an interview with another migrant. He volunteered to introduce me to another Filipino who plays for a team in the bowling tournament who then later introduced me to Espinosa. Espinosa said that during the Sundays they meet, competitors do not talk 'religion.' Although the group is open to non-Christian organisations, there are no takers.
} 


\section{'Out of necessity': births and transformations}

The Sydney Fiesta Cultura started as a sports gathering of Filipino-Australians in 1976, before the arrival of the so-called 'mail-order brides,' according to Manuel Castillo, the president of Philippine-Australian Sports and Culture Incorporated (PASCI). ${ }^{3}$ What was an initiative to play 'un-Australian' sports like basketball soon became an institution of 'culture' and 'ethnic economy.' For these initiatives, Castillo won the 2011 New South Wales Premier's Awards for Arts and Culture and later the Medal of the Order of Australia (OAM), while PASCI was recognised by the NSW Government for its marketing of multiculturalism in 1992. The PASCI experiment in diaspora philanthropy began with a fundraiser for disabled athletes from the Philippines to participate in the Pacific School Games in 1988 (PASCI 2010). Since then, the organisation has established a migrant community 'tradition,' which the former Australian Prime Minister Kevin Rudd recognised as contributing to Australia’s ‘social and economic development' (PASCI 2008: 5). In 2009, almost 20,000 attendees paid AU\$15 a ticket to consume 'Filipino' food, music and culture. Businesses commonly associated with sponsoring immigrant consumption—such as remittance centres, international call cards, banks, real estate agencies - also invest in the fiesta. The food stalls, stores and businesses that fill Fairfield showground rent spaces for an undisclosed amount. The production of the fiesta, however, incurs other expenses: rent of the venue, light and sound equipment, entertainers’ fees, police enforcement, rides, 10 percent Goods and Services Tax (GST), and prize money for the beauty queens. With such expenses, the show does not profit as much as is commonly perceived by its critics, according to Castillo. Nonetheless, PASCI continues to organise the show every year to raise funds for its philanthropic work, which include scholarship grants awarded to the Technological University of the Philippines to support engineering students, and the equipment and tools from Australian institutions, like the Sydney Dental Hospital, which PASCI successfully delivered to the City Mayor of Manila. For Castillo, his group diligently puts together a show not simply in the service of Filipino-Australians but also for the material benefit of people 'back home.'

'Out of necessity' is the expression that summarises the history of the Sydney Fiesta Cultura. In the yearly souvenir program is a narrative of the PASCI's early attempts to gather the Filipino community in Sydney (PASCI 2010). According to Castillo, the

\footnotetext{
${ }^{3}$ Interview with Manuel Castillo in Bangor, New South Wales on October 24, 2009.
} 
celebration aims to mark the 'good life [of Filipinos] in Australia, to uplift the youth's identity, and to promote trade between Australia and the Philippines. ${ }^{44}$ His answer is an indirect address to the emerging migrant community to be a conduit of philanthropy; that is, the new wealth made possible in Australia is also what engenders transnational giving. The discourse of 'thanksgiving,' then, is a dominant theme of the Sydney Fiesta Cultura, as is evident in the display of the Philippine and Australian national flags, the invocation of a 'fair go' multiculturalism and the acceptance of Filipinos within the multicultural fold, amongst other paeans to Australian generosity. More importantly, the expansion of the fiesta from being a Palarong Filipino (Filipino Games) to an ethnic celebration dedicated to philanthropy reflects the growth of the community itself. In 1988, at a time when the group was exponentially expanding (37 percent of all Filipinos arrived in Australia between 1981 and 1990, compared to 20 percent between 1991 and 2000), there was a move by PASCI to call the Filipino Games the 'Grand Philippine Fiesta.' 1988 was the year some 10,000 patrons attended the New South Wales State Sports Centre in Homebush (PASCI 2010). Castillo thought of expanding the sports event by putting in a beauty contest, entertainment show, booths and stalls-a town fair, so to speak. ${ }^{5}$ The success of the fiesta was apparent in the ever growing number of attendees, which had swelled to 25,000 in 1991, and in the New South Wales Government granting the event a Multicultural Marketing Award in 1992.

A curious development happened in 2002 when PASCI decided to change the Grand Philippine Fiesta to the Sydney Fiesta Cultura. According to Castillo, president of the PASCI board of management, which consists of unpaid volunteers, the change reflected the show's vision to dilute the event's ethnic-Filipino identification. 'Para hindi masyadong identified na Filipino' [So that it (the show) is not very much identified with the Filipino], he said. ${ }^{6}$ One clear gesture of the fiesta's 'de-Filipinisation' is the curious spelling of 'cultura' in its new name, 'Fiesta Cultura Sydney.' The word 'culture is commonly translated in Filipino as 'kultura' because the old alphabet does not include the letter 'c'; the hybrid 'cultura' is not used. A conscious bid to have a transcultural appeal is evident here. While it may seem ironic that an ethnic event strictly celebrated in the name of Filipino uniqueness and loyalty to a 'national identity' seemed to embrace a generic Australian multiculturality, the move can be understood as a

\footnotetext{
${ }^{4}$ Interview with Manuel Castillo in Bangor, New South Wales on October 24, 2009.

${ }^{5}$ Interview with Manuel Castillo in Bangor, New South Wales on October 24, 2009.

${ }^{6}$ Interview with Manuel Castillo in Bangor, New South Wales on October 24, 2009.
} 
commercial gesture more than anything else. Yet, the inclusion of performances by other 'ethnic' groups, such as the Grupo Foclórico da Madeira Inc, a PortugueseAustralian group, in the 2002 celebration, and others in subsequent years, has not diminished the show’s all-Filipino audience.

The event, then, was a consolidation of the Filipino community's expansion; it had become a critical venue in the recognition (and assertion) of the presence of another ethnic group in multicultural Australia. This solidifying of identity, however, was accomplished at the expense of acknowledging the community's feminised migration, which I address in the following sections. Indeed, there was no trace of the so-called 'mail-order bride' in the Fiesta, or at least, none that an outsider could easily perceive.

\section{Who is the 'Filipino' in Australia?}

The 'Filipino' in Australia is a 'Filipina.' As a sexualised Other of Australianecessarily a racialised Other as well—naturalised Philippine-born citizens are collectively feminised and known under the rubric of 'mail-order brides.' The gendered specificity of Filipino migration has positioned the community as an underclass, easily discriminable because of the weight of being non-white, 'Third World-looking people' (Hage 1998: 18-19) and further burdened as the 'whore' immigrant class in Australia. Following the trickle of Spanish-Filipino mestizos who migrated in the late 1960s, after the relaxation of Australia's White Australia policy hundreds of Filipino women started to arrive in the 1970s. The migration flow was established in that decade either through correspondence for friendship and potential romantic relationships or through meeting Australian men visiting the Philippines. The highest percentage of arrivals, however, was between 1981 and 1990, more than twice as many as the number of overseas-born Filipinos ('Community Information Summary: Philippines-born’ 2006). This period was also characterised by large-scale family reunion migration. This proved to be the most definitive of diasporic exits from the Philippines to Australia, as noted in the wide scholarship on the 'mail-order bride' phenomenon in Australia (Boer 1988; Cooke 1987; Perdon 1998; Hennessy 2004; Mowatt and Wall 1992; Tibe-Bonifacio 2003). Despite changes in the migration in-take since the 1990s, which focused on highly skilled professionals — for instance, (male) temporary workers in Western Australia— the Australian Filipino community still bears the legacy of its feminised migration. In 2006, 42,680 of Philippine-born Australians were male, while 77,854 were female 
(Australia Bureau of Statistics 2007a). This is significantly more balanced than ten years earlier when men numbered 32,326 compared to 60,623 women (Australia Bureau of Statistics 2007b). While international marriage migration is not entirely Australiaspecific - more Filipino women are married to North American and Japanese menAustralia comes third: 29,284 Filipinos have Australian partners, and some eight percent of Filipinos in Australia are married to non-Filipino citizens (Commission on Filipinos Overseas 2011). The emergence of Australia as an economic and political power in 'Asia Pacific' — after the USA, Japan and China-is inextricable from the feminisation of 'dependent' nation-states like the Philippines (Tadiar 2004: 40-41), whereby the continuing feminisation of labour flows has penetrated the private sphere of marriage and family in host and home countries alike (Tolentino 2001: 9).

The visibility of non-white, 'Third-World looking,' and female people in white Australia raises the question of illegitimate citizenship, particularly that of sexualised citizenship. These women migrants inhabit a marginal space that renders them at once invisible and all-too-visible. The Philippine-born community has been subject to a ‘sexualised citizenship’ on top of racialised Otherness. I define ‘sexualised citizenship’ as conferment of nationality and the expropriation of belonging based on the sexual division of labour and the goods and services rendered by those who received the citizenship. The migration of 'mail-order brides' en masse in the 1970s is overdetermined by a reading of what Filipino women can do with their sex. This means performing sex, giving birth as the reproductive role of their sex, unpaid domestic labour premised on sexual differences, and the specialised affective labour that the Filipino racialised and sexualised class provides. Filipino women buy their citizenship through the exercise of their sex; the lowest 'trick' in jumping the immigration queue. While the racialised citizen is tolerated, the sexualised citizen is permissible - to a certain degree-for the affective labour she embodies. The Filipino wife is also readable by the function she plays in Australia's imagined project of modernity: her presence either in the outback or in a picket-fence-lined white suburb neutralises a racist and colonialist past through a 'multiculturalism' that has generally subsumed her, while at the same time, permitting her to experience a systemic inequality.

The citizenship premised on the undesirable, yet usable, sexual Other that Filipinos possess in their 'southern' migration has captured the community singularly like no 
other immigrant group in Australia. While racialised citizenship is inevitably also sexualised, Filipinos suffer an unmatched disrepute that is hardly ever explained as a consequence of global forces, women's position as the 'second sex' or the specificities of Philippine postcoloniality. The 'mail-order bride' is a 'problem' because there are women who are more 'prostitutable' than others. The problem is exacerbated by culturally specific factors that differentiate between groups of women: for instance, the Indian woman is less sexualised than the Thai, but no less exotic. A sexualised citizenship essentialises subjects so that they believe the negative culturalised representations about them, or at least, they behave as if they believe their construction. I raise this point because doing ethnography of sexualised citizens reveals a deep-seated paranoia among participants that my research will again remind the community that it is more 'prostitutable' than others. The caution exercised by Filipino-Australians in general—but specifically those who lived through the scandalous 'mail-order bride' years - to measure their proximity from the 'mail-order bride' is a latent feature of sexualised citizenship. It is a symptom of fear, anxiety, humiliation, and a sadness that does not cast a long shadow in other immigrant communities. ${ }^{7}$

The presence of the Filipina as a 'social problem' became an even more pressing concern when women and children were murdered by Australian husbands, partners and fathers. In 2011 the Centre for Philippine Concerns-Australia (CPCA) published an extensive report on the incidences of killings and domestic violence involving Filipino women in Australia. Since 1980, 27 women and seven children have been killed and five women and two children have disappeared (CPCA Brisbane 2011). Moreover, so extensive was the coverage on the 'mail-order bride' that university theses, academic studies and investigative reports followed the media's sensationalised accounts of the phenomenon. In popular culture, the 'mail-order bride' as a caricature penetrated the Australian collective imagination in the character of Cynthia in The Adventures of Priscilla: Queen of the Desert (Eliott 1994). This Australian cult film is complex in playing with the intersections of sexuality, class, race and indigeneity, yet it is not critical enough in its depiction of a gold-digging Filipina whore beyond redemption. Two other notable Filipino Australians, Rose Porteus, the ex-maid and socialite

\footnotetext{
${ }^{7}$ In another related project, I explored the 'disappearance' of sub-groups such as the Spanish-Filipino and Chinese-Filipino as a consequence of this racialisation. I argued how the very fabric of Australian multiracialism seeps into and accommodates a kind of fracturing — a re-grouping and re-definition of identities—amongst former Filipino nationals.
} 
embroiled in a drama involving a dead husband from one of Australia's most prominent mining families, and Vivian Solon Alvarez, the mistakenly deported 'Australian,' are neither people nor simple media representations, but real-life caricatures of the grotesque figure of the sexualised Filipino-born citizen. ${ }^{8}$ As Marshall notes, tersely, 'Filipino women who are not "brides,” therefore, simply do not exist' (1997: 68).

The discussion so far has exposed the extraordinary position by which FilipinoAustralians find themselves in relation to philanthropic exercises sourced from the labour — both gendered and sexualised_-of women. While earnings from the pageant are modest, to say that the central attraction of the fiesta is the pageant is an understatement. It was the most anticipated activity of the celebration, the finale of a program that finished at midnight, with Miss Philippines-Australia 2009 in barely covered clothes sashaying on the makeshift stage. Her appearance embodies a sense of the diasporic community's desperation now turned into a mode of hopeful empowerment, one given form by the philanthropy of sexualised citizens.

\section{Transnational bodies, sexual labour and the politics of giving}

Framing the politics of diaspora philanthropy vis-à-vis feminised migration allows us to recognise the complicit dependence of philanthropic acts on the political economy of the gendered body, that of the 'third world woman' in particular. The concept of embodiment posits that the body is the main battleground over which gender politics is constructed, discursivised and practiced (Conboy et al. 1997: 1-3). The body and the way it lends itself to be a symbol, an agent and a material site have been studied in many ways: as a menstruating and reproducing body (Martin 1989); as a violable body (MacKinnnon 1989); as commodity (hooks 1992); as 'sexage’ (Guillaumin 1995). The body understood as text, container and signifier of meanings refigures 'female' subjectivity as a pool of ideas, meanings, rituals and performances that constitute a sexualised reading of what a woman should look like, how she should be and what her body performs or gives platform to (Bordo 1997: 90-91). The feminine body is a

\footnotetext{
${ }^{8}$ Rose Lacson Porteous married iron ore magnate, Lang Hancock, father of Gina Rinehart, now the richest woman in Australia. She landed in Australia's society pages as the tacky, gold-digging Filipina wife who was later accused by Rinehart of murdering Hancock. A courtroom battle then ensued; Porteous was exonerated but remained notorious for her lavish lifestyle and her marriage to Hancock's friend (see Wainwright 2002). Vivian Solon Alvarez, an Australian citizen who came as a 'bride,' was mistakenly deported by immigration authorities as an illegal immigrant in 2001; she was later on 'discovered' in a hospice in Pampanga, Philippines. She reportedly received \$4.5 million compensation from the Australian government for damages (Anderson 2006).
} 
contested site of dominant ideology and of the discourses that the dominant ideology suppresses. That is why the feminine body gets bruised, abused, displayed, altered, molested, worshipped, bound, enslaved, raped and killed. But this embodied subjectivity does not sit passively; it is also capable of action, whether in passivity or in a state of aggression. For example, reproduction is action in passivity, so to speak. The female body can also be a source of strength and a vehicle imbued with radical potential —in other words, of agency — to transform itself and effect change in a woman's environment. The body of the woman, especially the technologies of the gendered body, and what it can accomplish materially, is open to many possibilities that usher in change and negotiate social reality (Balsamo 1996: 3-6). And since 'the body is our general medium for having a world,' according to Merleau-Ponty (in Reischer \& Koo 2004: 307), the body is changed by the vicissitudes of a racialised patriarchy that marks it as a target. Yet it also has the capacity to resist dominant (and) oppressive practices (Reischer \& Koo 2004: 307).

The flesh that embodies cultural, linguistic and ethnic separation, but also the capital for exchange - 'third-word difference'-is also the receiving end of corporeal violence. The bodily harm experienced by 'mail-ordered brides' in Australia has been well documented: victims were drowned, shot, knifed, slashed, hit on the head with a hammer, pushed into water, strangled, cut up, stabbed thirty times, strangled with a lamp cord and then set on fire, bashed in the head, among others. Sometimes the body of the 'mail-order bride' was simply made to 'disappear' as if she never existed (Cunneen \& Stubbs 1997: 55-79). On the other hand, however, the body of the Filipino woman is also the 'receptacle' of biological reproduction, and thus of familial values that uphold the virtues of the nation-state. Her capacity in Australia to reproduce the mixed-race child is a trace of her sexualised migration, the returned profit from a 'foreign investment' in the third world. The other extreme of the spectrum where the body is desired, caressed, loved, touched and valorised is also part of discursive formation of the body as ‘docile’ and as an object of 'surveillance’ (Balsamo 1996). Central to the issue of the Filipino 'bride' is a body that can be 'ordered'—a package that undergoes a geographic dislocation and a cultural devaluation — and be 'in order' to perform bodily functions such as sex and reproduction. Through the body, the 'ordered' Filipino woman became an agent who has literally 'given birth' to a set of new citizens that continues to alter the racial and social landscape of (white) Australia. 
Without insinuating that candidates in Miss Philippines-Australia from interracial marriages are daughters of 'mail-order brides,' or without reducing the beauty pageant to a 'mail-order bride'-only phenomenon—elitist and culturally essentialist to begin with-I would argue that for a community whose embodiment has been heavily racialised and sexualised, beauty contests, not unlike reproduction, are a form of sexualised labour. The Filipino woman as wife and mother-in other words, her capacity to perform sexual and reproductive labour, not to mention her lifetime of unpaid domestic work-is a border-crossing body. The Filipino-Australian woman as body for diaspora philanthropy, on the other hand, is an investment whose profit is gained by the crossing of transnational borders. I would argue that other young women, say, Fijian-Australian or Indian-Australians, who perform the same symbolic and material labours, do not invite sexualisation in the way Filipino-Australians do.

The Sydney Fiesta Cultura sells the beauty/body of the Filipino-Australian woman in the context in which the community is built. Moreover, it promotes a measure of looking back, a recognition of one’s heritage, and a celebration of one’s ethnicity, that renders Filipinos as 'different' and thus at odds with their desired fate in Australia. This is evident in the attempts of some young women to speak in Filipino when presenting themselves or to sing a Filipino song with an accent. Yet the fiesta is also a venue of hybridity, in which the young contestants negotiate their characterisation as 'good' Filipinas - conservative, elegant, eager to please, submissively 'Oriental'—and as 'lucky' Australian women-educated, articulate, feisty, independent-minded, the liberated modern subject. Such clichéd self-identification is forged under the belief that one can occupy the extreme ends of the spectrum. This is, I argue, a paean to the very values of immigrant indebtedness passed on to Filipinas by their elders who recognise how 'lucky' they are to be in 'multicultural' Australia: to be different yet accepted; to be unwelcomed yet tolerated. But this articulation of hybridity as one of the many 'gifts' bestowed by migration and partial integration into white Australia is not entirely explained in terms of ethnicity or cultural and racial otherness. The fiesta itself is a gendered performance of thanksgiving, and the masculine operations of the celebration betray how this feminised community has an internalised patriarchal orientation. While Miss Philippines-Australia is a feminised institution, the fiesta—operated, managed and envisioned by the mostly male community leaders of PASCI-is particularly masculine. Not unlike its early rationale as a sports and recreation group for male Filipino migrants, 
the fiesta exhibits a gendered division of labour as well. On the one hand, the sports events such as golf, tennis, basketball, to mention a few, held prior to the fiesta are dominated by fathers, sons and brothers, and culminate in trophy-raising ceremonies and coverage in ethnic newspapers. On the other hand, the fiesta proper is the 'family day’ on which mothers, sisters, daughters, and children are entertained. Like many gendered events, the day of the fiesta is planned according to the roles ascribed to women and children: Manila-based celebrities and heartthrobs surrounded by screaming mothers and daughters, the Ferris wheel and other rides, the games, and of course, food, an area traditionally managed by women. Sandya Shukla (2003), in analysing Indian cultural festivals in Britain and the USA, rightly points out that public performances are not received by a passive diaspora. While migrants recognise a 'cross-temporal legibility' of Filipinoness - time and space are compressed in a fiesta—they conduct the fiesta from the specificities of the migrant condition (2003: 75). Similarly, Avtar Brah observes that class structures and behaviours as practiced in the old country are not replicated by immigrants, exemplified by how the caste system in India is reformulated in the new setting (1996: 30). The specific migration history of Philippine-born women and their underclass position in Australia is not, however, clearly evident in the celebration's rationale and program. Moreover, the loudness by which the uses of the female body for philanthropy are heralded speaks of a muting, a forgetting, and even a denial in the community about its hyperfeminised past.

Recent scholarship reads beauty contests as an exercise in good citizenship whereby women perform civic duties by articulating sentiments that promote the positive values of health, fertility and productivity that in turn reflect national aspirations (Banet-Weiser 1999: 202-4). This is a far cry from reading such contests as 'culturally irrelevant or as an anachronism,' as typified by feminist critiques of the ways women are objectified in such contests (Watson \& Martin 2004: 18). Migrant women, however, do more than perform 'good citizenship.' Young Filipino-Australian women perform the demands of overlapping ‘dual citizenship' duties so that the labour extracted for the conduct of beauty contests provides a conduit for transnational philanthropy. The Filipino migrant community's diaspora philanthropy, then, is all the more problematic and needs serious reflection. This is particularly important given that this community's growth was made materially possible by ‘mail-order brides’ whose physical abuse by white male power was endured by the transborder, transgressive bodies whose exposure to the public is 
reminiscent—if not a painful parody — of the economic and affective transaction between Filipino women and Australian men. The Sydney Fiesta Cultura's main event is a conscious disavowal, an effort by the members of the community in general and by professional ethnic gatekeepers in particular, to instigate a forgetting by eliding the links between the source of their oppression and the uses of the female body to celebrate the triumphs of their migration through charity. As a Filipino in Sydney participating in the fiesta but also as a non-immigrant outsider, the irony of mixed-race women whose bodies are platforms for fundraising was not lost in me. Having been exposed to subtle forms of racism and sexism myself in Australia, and still preparing an ethnography of the Filipino community, it is not easy to reconcile the asymmetry between the beauty contests, on the one hand, and on the other, the violent deaths of 'mail-order brides' and bruised bodies, the widespread representation of the Filipino as a woman for sale and the jokes that Australians have come up with in their daily conversations. The spectre of the dead 'mail-order brides' who were unfortunate to survive the completion of a transnational economy of desire in the form of a happy interracial, possibly middle-class families, haunts every beauty contest ever held and that will be held in the FilipinoAustralian community. As I sat listening to families and friends cheering, mixed-race and 'native' young women performed their 'dual citizen' civic duties as beautiful, ablebodied females. The hyperfemininity of the Filipino woman as 'capital' in an economic transaction such as marriage is reproduced in these contests. More so, upon closer scrutiny, one may read the competition between 'native-looking' and 'mixed-race' woman as a history of Filipino migration, putting into sharp relief the segregation between those whose mothers were 'brides' and those whose mothers were not.

The subjectivity of the 'mail-order bride,' while erased by festivities such as the Sydney Fiesta Cultura that do not dare mention her name, cannot be fully extinguished. One may argue that Filipino-Australian material culture, and their use of media and print production, is al rooted in the circumstances of Filipino migration, and that these expressions are responses to the Australian multiculturalism that is grounded on racist and sexist parameters. In this context I argue that the diaspora philanthropy spearheaded by PASCI and the Sydney Fiesta Cultura is a targeted response to global forces siphoning resources and investments in the form of charity. A beauty contest as a communal activity seems to be not a choice but a given in a group whose female population outnumbers that of the male. In the late 1980s up to the 1990s, the Mrs. 
Philippines-Australia was annually conducted. This beauty contest involved the 'missus' whose names are hyphenated and Anglicised. The Philippine Community Herald advertised the event in its pages and included photographs of the contestants; in other pages was news about the disappearance, violence inflicted on and even death of Filipino women. The very foundation of 'Filipino-Australianness' and the philanthropy of the first-world stand on the very sadness of a community of 'brides.'

While the relationship between diasporic communities and philanthropy is clear and often interpreted as part of the new economy of a globalised world, the gendered and sexualised face of diaspora philanthropy is not as neatly articulated. While this article focused on 'mail-order bride' migration in Australia, pockets of marriage migration exist all over the world. There are 154,871 Filipino nationals married to North Americans, 108,245 married to Japanese nationals, 29,284 to Australian nationals, 15,350 to Canadian nationals, 12,363 to German nationals, to mention selected figures from statistics collected between 1989 and 2009 (Commission on Filipino Overseas 2011). This pattern of migration, while not totally made up of 'brides' (as there are grooms as well) is thoroughly feminised given that 92 percent of the marriage migrants are women (Commission on Filipino Overseas 2011). Excluded from the current discussion is the feminised migration of domestic servants, entertainers, factory workers and other low-skilled labourers caught in the traffic of the global migration today. They, too, contribute to the ongoing diaspora philanthropy to the Philippines. While it may be difficult to ascertain how many of these geographically dispersed communities do beauty contests and how much of the funds raised go to charities, the broader feminisation of migration of Filipinos highlights the intimate connection between women's labour and diaspora philanthropy, and women's labour and the neoliberal market.

\section{Conclusion}

The participation of a feminised Philippine-born community in Australia in the muchvalorised performance of diaspora philanthropy worldwide raises the rather discomforting question of the gender of transnational giving. The conduits that enable the gathering of donations and facilitate their dispensation operate on gendered parameters specific to the contingencies of the community as a collective body in the new country. The Sydney Fiesta Cultura is one example of this problematic juncture 
between performing transnational philanthropy through sexualised forms of fundraising. This poses a particularly contentious politics of doing charity by any means possible irrespective of what such an action reproduces. The diaspora philanthropy of sexualised overseas Filipinos reveals a perpetuation of the feminisation that led to the migration of women as 'brides' in the first place. Filipino-Australians like other Philippine-born migrants in the first-world acquire the masculine status of the wealthy nation. Doing cross-border charity feminises impoverished Filipinos in the Philippines and highlights the immense income gap between the north and the south. Further, the subsequent masculinisation of the immigrant class does not challenge their feminised status in Australia. If anything, the masculinisation is compensating for the continuing colonialist relations in the destination country.

This new transnational class identity blurs the deeply entrenched class stratification in Australian society in which Filipinos on the whole occupy a bottom rung. In that context, the Sydney Fiesta Cultura is a production in which ethnicity is designated and reproduced through a 'managerialist' treatment of culture decided by a few and consumed by the multitude. Oftentimes, working class migrants are consumers of middle-class interpretations of 'ethnic' culture. The 'valorisation of the middle class' migrant, a tendency that Hage (2003: 113) identifies as common to marginalised communities in Australia, also applies to the fiesta. That the event showcases the most talented, the most articulate and the prettiest Filipino-Australians indicates a claim to this 'middleclassness,' especially when candidates highlight what university they attend or whether they danced ballet as children. This reading of class, needless to say, intersects with the larger subjugation of the class of women known as 'mail-order brides' that Filipino-Australians orchestrate to conceal in their cultural production. The body and sexual labour of the 'mail-order bride' persists and has found new forms of expression, such as the exercise of diaspora philanthropy in liberal democracies. Whether beauty contest or a fiesta, both material culture performances exemplify the broader hyperfeminised appropriation of coloured women's bodies and continued injustices based on gender. 


\section{Reference List}

Anderson, L. 2006, ‘\$4.5m payout to Alvarez,' The Advertiser, November 30. Online, available: http://www.adelaidenow.com.au/m-payout-to-alvarez/story-e6frea6u-11111

Australian Bureau of Statistics 2007a, '2006 Census of Population and Housing Australia: Country of Birth of Person (Full Classification List) by Sex.’ Online, available: http://www.censusdata.abs.gov.au [Accessed 18 February 2010].

Australian Bureau of Statistics 2007b. '2006 Census of Population and Housing Australia: Country of Birth of Person by Sex for Time Series.' Online, available: http://www.censusdata.abs.gov.au [Accessed 18 February 2010].

Balsamo, A. 1996, Technologies of the Gendered Body: Reading Cyborg Women. Duke University Press, Durham, NC, \& London.

Banet-Weiser, S. 1999, The Most Beautiful Girl in the World. University of California Press, Berkeley.

Basa, C., Villamil, L., \& de Guzman, V. 2009, 'Migration, Local Development and Governance in Small Towns: Two Examples from the Philippines.' International Institute for Environment and Development. Online, available: http://pubs.iied.org/pdfs/10576IIED.pdf [Accessed 16 August 2011].

Boer, C. 1988, Are You Looking for a Filipino Wife?: A Study of Filipina-Australian Marriages. General Synod Office, Sydney.

Bordo, S. 1997, 'The Body and Reproduction of Femininity,' in Writing on the Body: Female Embodiment and Feminist Theory, (eds) K. Conboy, N. Medina \& S. Stanbury. Columbia University Press, New York, 90-110. 1993, Unbearable Weight: Feminism Western Culture, and the Body. University of California Press, Berkeley.

Brah, A. 1996, Cartographies of Diaspora: Contesting Identities. Routledge, London \& New York.

Camara, C. 1996, An Expose of Filipino Culture: Spirituality and Religiosity Vs. Myths and Fallacies. Pag-asa Christian Fellowship Inc., Brisbane.

Commission on Overseas Filipinos. 2011, 'Number of Filipino Spouses and other Partners of Foreign Nationals by Major Country: 1989-2009.' Online, available: http://www.cfo.gov.ph/pdf/statistics/FS\%20BY_MAJOR_COUNTRY.pdf [Accessed 13 May 2010].

'Community Information Summary: Philippines-born.' 2006, Department of Immigration and Citizenship. Online, available: http://www.immi.gov.au/media/publications/statistics/comm.summ/pdf/Philippines.pdf [Accessed 25 January 2010].

Conboy, K., Medina, N., \& Stanbury, S. 1997, 'Introduction,' in Writing on the Body: Female Embodiment and Feminist Theory, (eds) K. Conboy, N. Medina \& S. Stanbury. Columbia University Press, New York, 1-12.

Cooke, F. 1987, Australian-Filipino Marriages in the 1980s: The Myth and the Reality. Australia-Asia Papers 37, Centre for the Study of Australian-Asian Relations, Griffith University.

CPCA Brisbane. 2011, 'Violent Deaths and Disappearances of Filipino Women and Children since 1980.' Available, online: http://cpcabrisbane.org/CPCA/Deaths.htm [Accessed 19 July 2010].

Cunneen, C. \& Stubbs, J. 1997, Gender, Race and International Relations: Violence Against Filipino Women in Australia. Sydney: The Institute of Criminology, Faculty of Law, University of Sydney.

Eliot, S. (dir.) 1994, The Adventures of Priscilla: Queen of the Dessert. Polygram Filmed Entertainment.

Garchitorena, V. 2007, Diaspora philanthropy: The Philippine Experience. The Philanthropic Initiative, Inc. and The Global Equity Initiative, Boston \& Cambridge.

Geithner, P., Chen, L., \& Johnson, P. 2005, Diaspora Philanthropy and Equitable Development in China and India. Harvard University Press, Massachusetts.

Guillaumin, C. 1995, Racism, Sexism, Power and Ideology. Routledge, London.

Hage, G. 2003, Against Paranoid Nationalism: Searching for Hope in a Shrinking Society. Pluto Press, Sydney. 1998, White Nation: Fantasies of White Supremacy in a Multicultural Society. Pluto Press, Sydney.

Hennessy, N. 2004, A Journey in Antipodean Land: The Filipino Heritage in Australia. Seaview Press, South Australia.

hooks, b. 1992, Black Looks: Race and Representation. South End Press, Boston.

Howson, A. 2005. Embodying Gender. Sage, London.

Johnson, P. 2007, Diaspora Philanthropy: Influences, Initiatives, and Issues. The Philanthropic Initiative, Inc. and the Global Equity Initiative, Boston \& Cambridge.

Kasinitz, P. 1992, Caribbean New York: Black Immigrants and the Politics of Race. Cornell University Press, Ithaca. 
Levitt, P. 2002, 'Migrant Philanthropy in Latin America: Move Over United Way,' ReVista: Harvard Review of Latin America. Spring issue. Online, available: http://www.drclas.harvard.edu/revista/articles/view/15 [Accessed 30 March 2010].

MacKinnon, C. 1989, Toward a Feminist Theory of the State. Harvard University Press, Harvard.

Martin, E. 1989, The Woman in the Body: A Cultural Analysis of Reproduction. Open University Press, Milton Keynes.

Marshall, L. 1997, 'The Representation of Filipino Women in Australian Film: The Case of Mail-order bride.' MA Thesis, La Trobe University.

Mowatt, J. \& Wall, D. 1992, Dealing with the Media: Filipino Women in Cross Cultural Marriages: A Training Course Manual for Community Workers. Filipino Women's Working Party, Jannali, NSW.

Ong, A. 2006, Neoliberalism as Exception: Mutations in Citizenship and Sovereignty. Duke University Press, Durham, NC, and London. 1999, Flexible Citizenship: The Cultural Logics of Transnationality. Duke University Press, Durham, NC, and London.

Orozco, M. \& Rouse, R. 2007, 'Migrant Hometown Associations and Opportunities for Development: A Global Perspective.’ in Migration Information Source: Fresh Thought, Authoritative Data, Global Reach. Online, available: http://www.migrationinformation.org/feature/display.cfm?ID=5 [Accessed 28 August 2010].

Orozco, M. \& Welle, K. 2009, 'Hometown Associations and Development: Ownership, Correspondence, Sustainability and Replicability.' Social Science Research Council. Online, available: http://www.ssrc.org/publications/view/6A12F169-3F55-DE11-AFAC-001CC477EC70/ [Accessed 6 May 2010].

Perdon, R. 1998, Brown Americans of Asia. The Manila Prints, Sydney.

Philippine Australian Sports \& Culture Incorporated (PASCI) 2010, 'Born Out of Necessity: Australia's Biggest Filipino Show.’ Online, available: http://www.pasc.org.au/AboutUs/AboutUs.htm [Accessed 18 February 2010]. 2008, 'Sydney Fiesta Cultura.’ [Souvenir program].

Reischer, E. \& Koo, K. S. 2004, 'The Body Beautiful: Symbolism and Agency in the Social World,' Annual Review of Anthropology, vol. 33, 297-317.

Saroca, C. 2002, Hearing the Voices of Filipino Women: Violence, Media Representation and Contested Realities. PhD thesis, University of Newcastle.

Shukla, S. 2003, India Abroad: Diasporic Cultures of Postwar America and England. Princeton University Press, Princeton.

Tadiar, N.X.M. 2004, Fantasy-Production: Sexual Economies and other Philippine Consequences for the New World Order. Ateneo de Manila University Press, Quezon City.

Tibe-Bonifacio, G. 2003, 'Filipino Women and their Citizenship in Australia: In Search of Political Space.’ PhD thesis, University of Wollongong.

Tolentino, R. 2001, National/Transnational: Subject Formation and Media in and on the Philippines. Ateneo de Manila University Press, Quezon City.

Torres, T. 2011, 'World Bank: Philippines $4^{\text {th }}$ Biggest Remittance Recipient in 2010.” Online, available: http://www.abs-cbnnews.com [Accessed 10 November 2011].

Wainwright, R. 2002, Rose. Crows Nest: Allen \& Unwin.

Watson, E. \& Martin, D. 2004, 'Introduction.' in There she is, Miss America': The Politics of Sex, Beauty, and Race in America's Most Famous Pageant. (eds) E. Watson \& D. Martin. Palgrave Macmillan, New York, 1-23.

World Bank, 2011, Migration and Remittances Factbook 2011. $2^{\text {nd }}$ edition. International Bank for Reconstruction and Development, Washington, DC. 